\title{
Review
}

Drug/Regimen

Diabetes Metab J 2021;45:629-640

https://doi.org/10.4093/dmj.2021.0163

pISSN 2233-6079 · eISSN 2233-6087

DIABET\&S \& METABOLISM JOURNAL

\section{A Century of Progress in Diabetes Care with Insulin: A History of Innovations and Foundation for the Future}

\author{
Seung-Hwan Lee ${ }^{1,2}$, Kun-Ho Yoon ${ }^{1,2}$ \\ ${ }^{1}$ Division of Endocrinology and Metabolism, Department of Internal Medicine, Seoul St. Mary's Hospital, College of Medicine, The Catholic University of \\ Korea, Seoul, \\ ${ }^{2}$ Department of Medical Informatics, College of Medicine, The Catholic University of Korea, Seoul, Korea
}

\begin{abstract}
The year 2021 marks the 100th anniversary of the discovery of insulin, which has greatly changed the lives of people with diabetes and become a cornerstone of advances in medical science. A rapid bench-to-bedside application of the lifesaving pancreatic extract and its immediate commercialization was the result of a promising idea, positive drive, perseverance, and collaboration of Banting and colleagues. As one of the very few proteins isolated in a pure form at that time, insulin also played a key role in the development of important methodologies and in the beginning of various fields of modern science. Since its discovery, insulin has evolved continuously to optimize the care of people with diabetes. Since the 1980s, recombinant DNA technology has been employed to engineer insulin analogs by modifying their amino acid sequence, which has resulted in the production of insulins with various profiles that are currently used. However, unmet needs in insulin treatment still exist, and several forms of future insulins are under development. In this review, we discuss the past, present, and future of insulin, including a history of ceaseless innovations and collective intelligence. We believe that this story will be a solid foundation and an unerring guide for the future.
\end{abstract}

Keywords: Diabetes mellitus; History; Insulin

\section{INTRODUCTION}

The year 2021 marks the 100th anniversary of the discovery of insulin, which has greatly changed the lives of people with diabetes. Although polyuric states resembling diabetes mellitus have been known for over 3,500 years since the initial description in an Egyptian papyrus (1550 BC) [1], it was only after the discovery of insulin that meaningful treatment of diabetes was possible. However, there have been enormous innovations and breakthroughs in the development of various forms of insulins and antidiabetic agents in recent decades, leading to improved care of people with diabetes (Fig. 1). Insulin has also played a central role in the progress of modern science. Because diabetes has become one of the most prevalent metabolic diseases in modern society and is still continuously and rapidly increasing
[2-4], efforts to overcome the unmet needs of diabetes therapy are critical for human health. In this review, the past, present, and future effects of insulin will be discussed.

\section{THE HISTORY OF INSULIN DISCOVERY}

Before the discovery of insulin, evidence on the cause of diabetes started to accumulate in the late 19th century, which opened a gleam of success. In 1889, von Mering and Minkowski [5] reported that pancreatectomized dogs developed severe diabetes. The concept that internal secretion by the islets of Langerhans' of the pancreas control carbohydrate metabolism was suggested by Laguesse [6] in 1893, although it was still hypothetical. Based on the belief that pancreatic extract can cure diabetes, many attempts have been made to isolate the elusive

\footnotetext{
Corresponding author: Kun-Ho Yoon (D) https://orcid.org/0000-0002-9109-2208 Division of Endocrinology and Metabolism, Department of Internal Medicine, Seoul St. Mary's Hospital, College of Medicine, The Catholic University of Korea, 222 Banpodaero, Seocho-gu, Seoul 06591, Korea

E-mail:yoonk@catholic.ac.kr

Received: Jul. 15, 2021; Accepted: Aug. 8, 2021
}

This is an Open Access article distributed under the terms of the Creative Commons Attribution Non-Commercial License (https://creativecommons.org/licenses/by-nc/4.0/) which permits unrestricted non-commercial use, distribution, and reproduction in any medium, provided the original work is properly cited. 


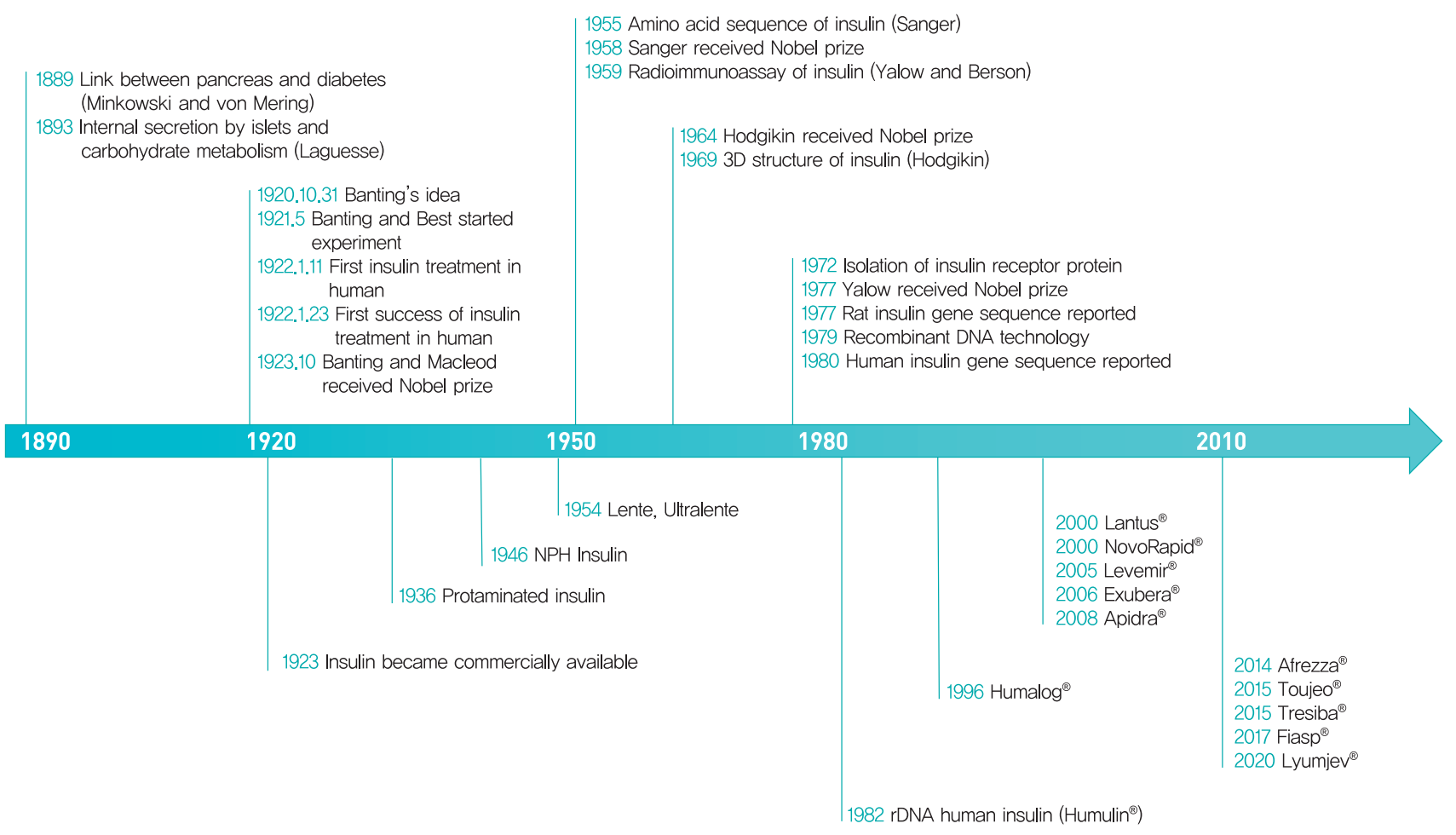

Fig. 1. Timeline of important discoveries, events (upper panel), and insulin products (lower panel) throughout history. 3D, threedimensional; NPH, Neutral Protamine Hagedorn.

internal secretion of the pancreas [7-10]. Although these attempts have largely failed due to inactivity or side effects of the preparations, some researchers reported possible effects of pancreatic extract in reducing glycosuria in dogs.

Frederick G. Banting made a breakthrough and landmark achievement in the discovery of insulin (Fig. 2) [11,12]. Returning from World War 1 and after working at the Toronto Military Orthopaedic Hospital, Banting established his private clinic in London, ON, Canada. He also started to work as an instructor at the Western University Medical School, London, ON due to economic difficulty in running his clinic. Banting's idea of ligating the pancreatic duct to induce selective degeneration of acini leaving islets and isolating internal secretion came up after reading an article by Barron [13] in preparing his lecture on October 31, 1920. A week after the idea, Banting met John J. R. Macleod, a renown authority in carbohydrate metabolism at the University of Toronto. Macleod, knowing the failure of many previous attempts and believing that isolation of pure soluble pancreatic extracts would be difficult, gave a skeptical response to Banting. However, Banting persuaded Macleod, and after a few months of hesitation, finally started the project in May 1921. An undergraduate student Charles H. Best was selected to join the team. Experiments with pancreatic duct-ligated dogs and pancreatectomized dogs as a source of pancreatic extract and recipient, respectively, were continued by Banting and Best and eventually started to show efficacy in August 1921. At the end of 1921, James B. Collip, a biochemist, visited Macleod's laboratory and helped with the project. His extraction protocol with $90 \%$ ethanol resulted in soluble insulin with enhanced purity, which overcame the critical technical hurdle. Leonard Thompson was a 14-year-old patient with type 1 diabetes mellitus (T1DM) weighing only $30 \mathrm{~kg}$. On January 11,1922 , he became the first human to receive insulin. After the first injection, his blood glucose level was slightly reduced, but an abscess developed, making him more acutely ill. However, another injection with refined extract prepared by Collip was given on January 23, which normalized blood glucose levels and eliminated glycosuria and ketonuria. The effect of insulin in several patients was reported in the March 1922 issue of the Canadian Medical Association Journal [14], and partnership with pharmaceutical companies, Eli Lilly (Indianapolis, IN, USA) and Nordisk (Bagsværd, Denmark), soon 

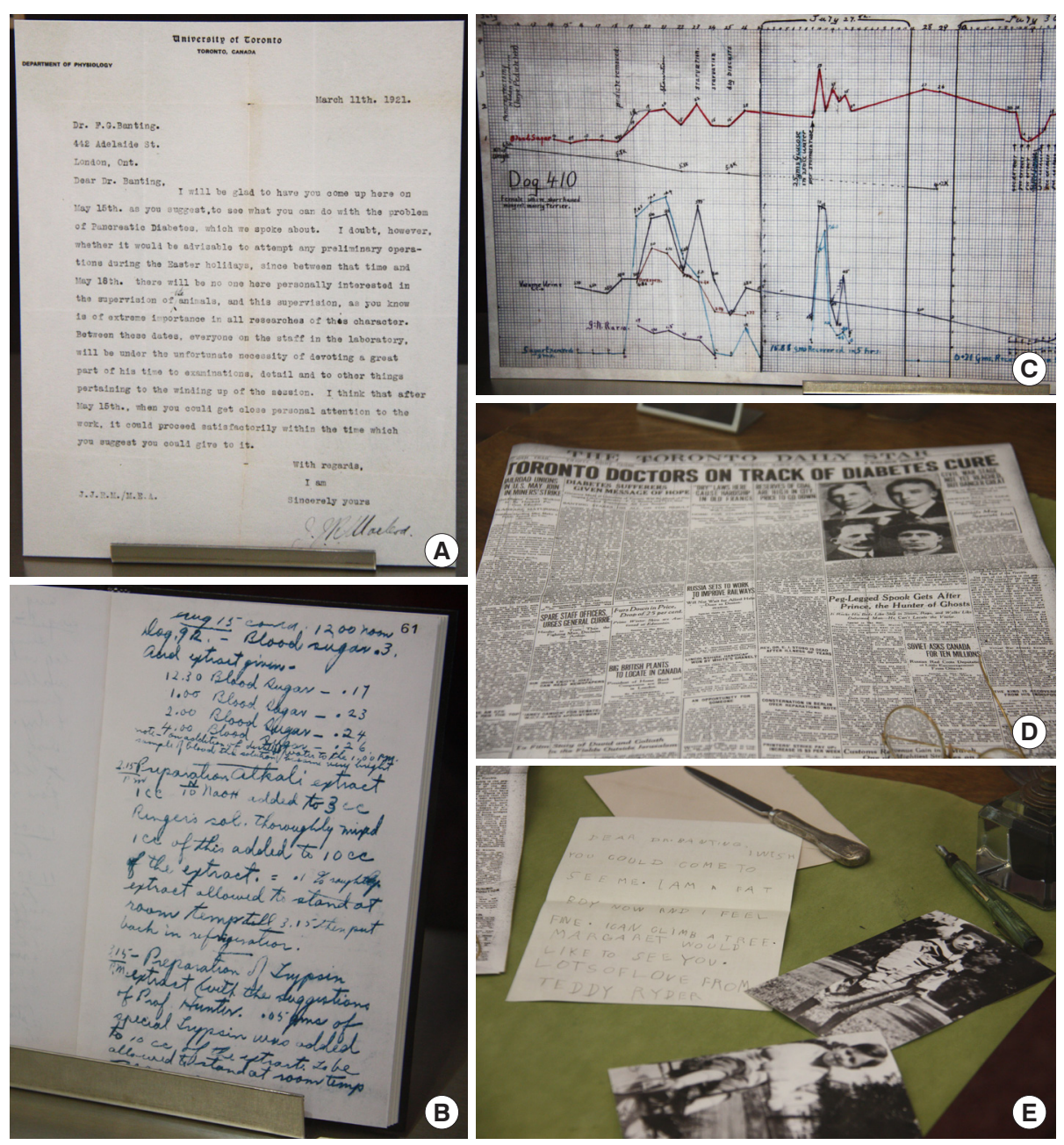

Fig. 2. The discovery of insulin by Banting and colleagues. (A) Letter of invitation from Macleod to Banting which was written on March 11, 1921. (B) A page from Banting and Best's notebooks describing the positive effects of their pancreatic extract on canine test subjects. (C) A flowchart describing the results of a dog experiment. (D) The newspaper with the headline 'Toronto doctors on track of diabetes cure' on March 11, 1922. (E) A letter from one of the early patient Teddy Rider to Dr. Banting saying that he is well after insulin treatment. Photos taken by Seung-Hwan Lee at the exhibition 'Insulin: Toronto's Gift to the World' at University of Toronto. Courtesy of the Thomas Fisher Rare Book Library, University of Toronto. More archival documents pertaining to the history and discovery of insulin can be accessed at https://insulin.library.utoronto.ca/. made insulin widely available. The Nobel Prize in Physiology or Medicine was awarded to Banting and Macleod in October 1923. The success story of insulin discovery was the result of a promising idea (although not entirely original), positive drive, perseverance, and collaboration of Banting and colleagues. To our surprise, all these events occurred over just 3 years.

Interestingly, Banting's initial idea that ligation of the pancreatic duct would induce selective atrophy of the exocrine pancreas and preserve insulin turned out to be physiologically incorrect. Not the trypsin in the acinar cells but the impurities of the extract was the problem, and Banting and Best realized that the non-duct ligated pancreas could also serve as the source of insulin. However, the pancreatic duct ligation model was later studied as a different means of treating diabetes. The existence of adult $\beta$-cell progenitors in the pancreas and the potential for $\beta$-cell regeneration through replication, neogenesis, or exocrine-to-endocrine conversion are topics of interest.
Some experiments have shown that duct ligation-induced injury can activate neurogenin 3-positive progenitor cells to expand the $\beta$-cell mass, and this theory has received renewed attention $[15,16]$. However, the results of this injury model have varied across laboratories, and later studies failed to show $\beta$-cell regeneration, leaving controversy [17-19].

\section{INSULIN: A KEY MOLECULE IN THE PROGRESS OF MODERN SCIENCE}

Insulin was the first protein whose amino acid sequence was elucidated, and this work was conducted by British chemist Frederik Sanger in 1955 [20]. Before his discovery, the amino acids in a protein were thought to be randomly arranged. In the 1940s, Sanger began to study how amino acids are linked in the two polypeptide chains of insulin. At that time, insulin was one of the very few proteins that were available in pure 
form. By using acids to breakdown the molecule and incorporating electrophoresis and chromatography, he was able to determine the amino acid sequence and disulfide bonds of insulin [21]. This was the beginning of proteomics, and the principle that every protein had a unique sequence earned Sanger the Nobel Prize in Chemistry in 1958 [22].

In 1964, the Nobel Prize in Chemistry was awarded to another British chemist, Dorothy C. Hodgkin, for her determinations of the structures of important biomolecules, such as vitamin B12, by X-ray techniques [23]. This method became an essential tool in structural biology. In fact, she became interested in the structure of insulin in 1934, and it took 35 years for the three-dimensional structure of this molecule to be unlocked [24]. Solving the crystal structure of insulin led to an understanding of its chemical reactions, cellular functions, and receptor binding. It also enabled mass production of insulin for medical use and modified the structure to create insulin with different profiles [23].

Radioimmunoassays (RIAs) are an important technique for measuring hormones and many biological substances that are still widely used. Yalow and Berson [25,26], developed RIA using radiotracers and antibodies to measure hormones with extremely low circulating levels. Following the measurement of animal insulins, they succeeded in measuring human plasma insulin in the late 1950s $[25,26]$. They were the first to propose the concept that peptides such as insulin could stimulate an immunologic response, which was accepted later. This novel technique opened a new era in the field of endocrinology and led to major advances in the diagnosis and treatment of hormonal diseases such as diabetes. Yalow received the Nobel Prize in Physiology or Medicine in 1977 (Berson died before the award was given) [27].

The presence of insulin receptors in the cell membrane and their relation to insulin bioactivity were suggested in 1971 [28], and receptor proteins were isolated in 1972 [29]. The sequences of rat and human insulin genes were reported by Ullrich et al. [30] in 1977 and Bell et al.s [31] group in 1980, respectively. The human insulin receptor gene was sequenced, and its relation to transmembrane signaling was unveiled in the mid1980s $[32,33]$. These findings were the cornerstone of insulinrelated studies and were followed by a tremendous amount of research on insulin signaling and insulin resistance [34,35]. The insulin signaling pathway regulates glucose, lipid, and energy homeostasis and controls proliferation, differentiation, and survival at the cellular level. Insulin binding to its tyrosine kinase receptor leads to the recruitment and phosphorylation of receptor substrates such as insulin receptor substrate (IRS) and Shc proteins. IRS activates the phosphoinositide 3-kinase (PI3K)-Akt pathway, which mediates most of the metabolic effects of insulin. The Shc-Ras-mitogen-activated protein kinase (MAPK) pathway controls cellular proliferation and gene transcription [36]. These pathways are regulated at several points by phosphatases or inhibitory proteins. Although these signaling cascades have not been totally elucidated, they have become the basis of understanding the pathophysiology of insulin resistance and its related diseases.

It is clear that insulin not only played a central role in the field of diabetology and clinical medicine but also greatly contributed to the advancement of various fields of modern science, including molecular biology, proteomics, and genomics.

\section{THE EVOLUTION OF INSULINS}

During a century of insulin use, it has evolved and many different options are currently available through modification of its structure or formulation (Table 1) [37]. Early on, its profile was poorly defined and inconsistent, and it was only extracted from animal pancreas. Currently, recombinant human insulin and insulin analogs with well-known pharmacokinetic (PK) and pharmacodynamic (PD) profiles are mainly used to mimic endogenous insulin secretion.

The initial insulin in a soluble formulation had a short action profile requiring multiple daily injections with large volumes and had a high risk of hypoglycemia. The first insulin preparation with extended action was introduced by Hans C. Hagedorn in 1936, when he found that adding protamine could prolong the effect of insulin [38]. Previous studies with emulsions of insulin in oil and lecithin or combined with vasoconstrictors failed to yield consistent results. Hagedorn applied the principle that proteins are least soluble at isoelectric $\mathrm{pH}$ and chose a highly basic protein protamine because the isoelectric point of insulin was below physiological pH (approximately 5.2). Protamine crystalizes with insulin hexamers and is dissolved slowly after injection. Therefore, the dissociation of insulin hexamers and the absorption of monomers into circulation are delayed. Neutral Protamine Hagedorn (NPH) insulin, or isophane insulin, was developed by Nordisk in 1946 by adding zinc to protamine insulin. With a longer duration of action and ability to be mixed with regular insulin in the same syringe, NPH improved glycemic control and patient acceptability with twice 
Table 1. Currently available insulins and their action time

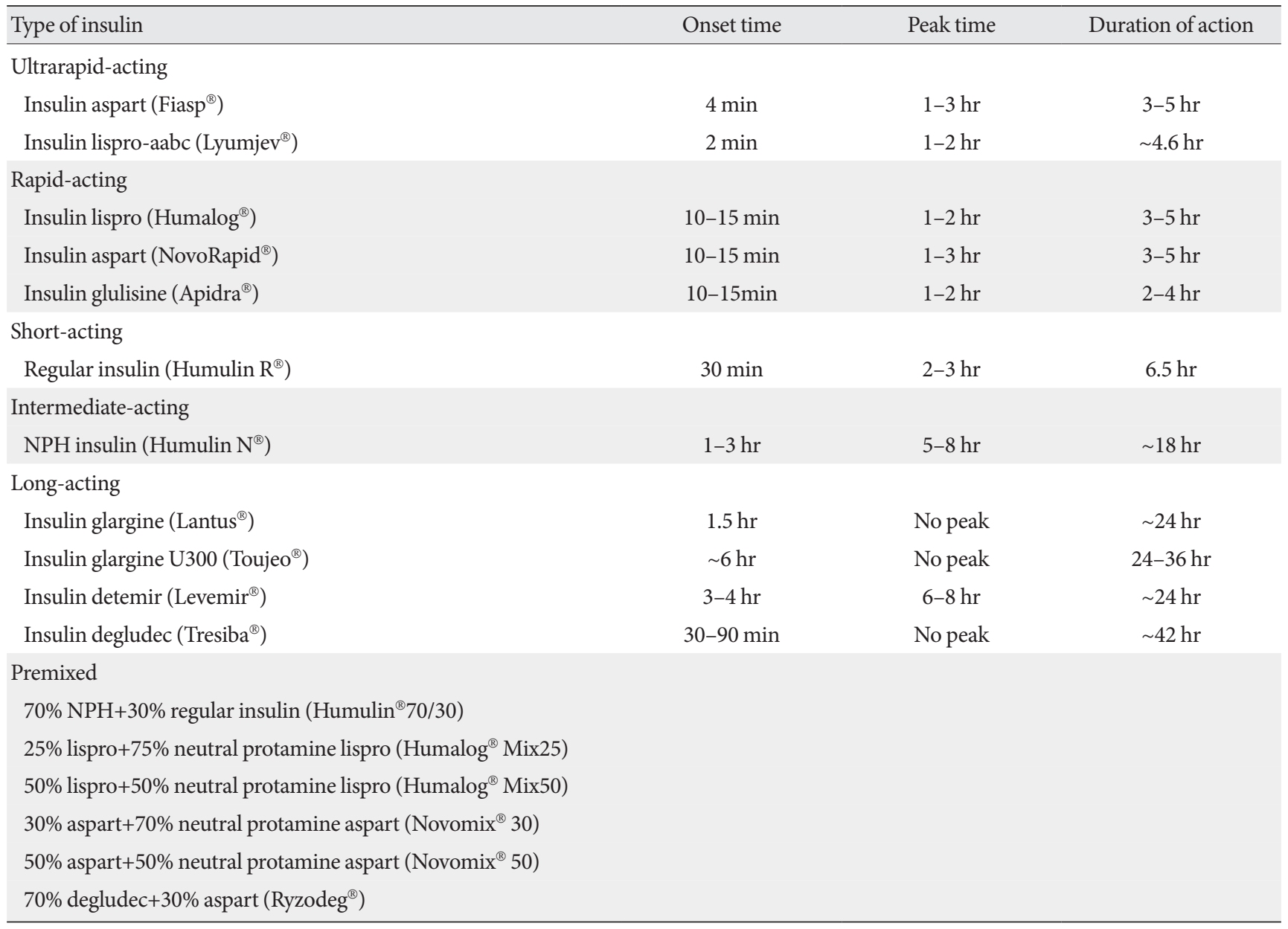

NPH, Neutral Protamine Hagedorn.

daily administration. Lente and ultralente insulin with a longer duration than NPH was developed in the early 1950s, but its use was limited due to high day-to-day variability in absorption, inconsistent peak patterns, and incompatibility with regular insulin $[39,40]$. A common drawback of animal insulins is the formation of anti-insulin antibodies leading to insulin resistance and lipoatrophy. Therefore, methods to produce highly purified preparations were important until the early 1980s.

Insulin was the first therapeutic protein to be produced by recombinant deoxyribonucleic acid (DNA) technology and approved for use in humans by the U.S. Food and Drug Administration (FDA) in 1982. This method for cloning and expressing genes in Escherichia coli was developed in the 1970s with successful expression of somatostatin and insulin in 1978 and 1979, respectively [41]. Because the gene sequence of human insulin was not known at that time, the genes for the A and $B$ chains of insulin were designed using the amino acid sequence. The collaboration of scientists working on chemical DNA synthesis, bacterial and mammalian gene regulation, restriction enzyme-based recombinant DNA technology, and cloning vectors and industry support (Genentech, San Francisco, CA, USA; and Eli Lilly) led to the birth of the first human insulin Humulin, which is still widely used [42].

The action profile of insulin depends on the formulation (monomer or hexamer) and the stability of hexamers, which determine the time to onset. Because there was a gap between the action profiles of earlier insulins and physiologic insulin secretion, recombinant DNA technology was employed to engineer insulin analogs by modifying their amino acid structure to change the PK and PD properties. The first insulin analog approved by the FDA was rapid-acting insulin lispro in 1996 [43]. By exchanging the amino acid proline at position B28 and 
lysine at position B29, faster dissociation of hexamers in subcutaneous space and absorption of monomers was achieved. Rapid-acting insulins with similar profiles, aspart and glulisine, were developed and marketed later and are now regarded as better mealtime insulins with comparable efficacy and reduced hypoglycemia compared with regular insulin [44]. Basal insulin helps stabilize glucose levels between meals and overnight and is frequently used as an initial option for insulin treatment. NPH insulin had a role as basal insulin for approximately 50 years until insulin glargine was approved in 2000 [45]. Asparagine was replaced with glycine at position A21, and two arginines were added at positions B31 and B32 to flatten the peak and provide a longer acting profile. These modifications in amino acid sequences shifted the isoelectric point to near neutral $\mathrm{pH}$ and enhanced chemical stability in a low $\mathrm{pH}$ solution. Therefore, injection of insulin glargine results in $\mathrm{pH}$ induced precipitation and slow release, enabling stable action [46]. More recently developed long-acting analogs, such as insulin glargine U-300 (3-fold concentrated) and insulin degludec, were both approved in 2015. The threonine at position B30 is removed and a side chain of 16-carbon fatty acid is added to lysine at position B29 via a glutamic acid spacer in insulin degludec [47]. Mutihexamer complexes are formed after subcutaneous injection and significantly delay dissociation and absorption, making insulin degludec the longest-acting (duration of action/42 hours) insulin analog to date. These newer long-acting analogs have a more physiological basal profile and provide comparable efficacy and a lower risk of hypoglycemia than first-generation long-acting analogs [48-50].

Several premixed insulins are also available that have the advantages of fewer injections, convenience, and preventing mixing errors [51]. However, because the ratio of individual com- ponents cannot be adjusted freely, these are more suitable for patients with regular lifestyle patterns. Human insulin mixtures (NPH insulin+regular insulin), analog insulin mixtures (rapidacting insulin analogs+its protaminated suspension), and a mixture of insulin degludec and aspart are currently available.

\section{THE FUTURE OF INSULIN THERAPY: SHORTER- AND LONGER-ACTING INSULINS}

Despite the great success and progress over a century, many physicians and patients are still reluctant to initiate insulin therapy due to the fear of injection, inconvenience, side effects such as hypoglycemia and weight gain, and social stigma [52]. Many researchers are on the road of developing insulins with improved profiles that can solve these problems (Fig. 3).

To more closely mimic normal physiologic insulin secretion in response to a meal, ultrarapid insulin analogs were developed and have been marketed recently. Faster aspart is a formulation consisting of niacinamide (for faster absorption) and L-arginine (for stabilization of the molecule) added to insulin aspart [53]. It appears in the bloodstream earlier after injection with doubled insulin concentration and increased glucose infusion rate during the first 30 minutes. It also exhibits faster on and faster off effects when administered via insulin pump. In both T1DM and type 2 diabetes mellitus (T2DM) patients, postprandial glucose control was superior with comparable hypoglycemia and tolerability compared with insulin aspart $[54,55]$. Ultrarapid lispro is a formulation of treprostinil (for local vasodilation) and citrate (for increasing vascular permeability) added to insulin lispro [56]. This also shows superior postprandial glucose control and noninferior glycosylated hemoglobin (HbAlc) lowering effects compared to insulin lispro

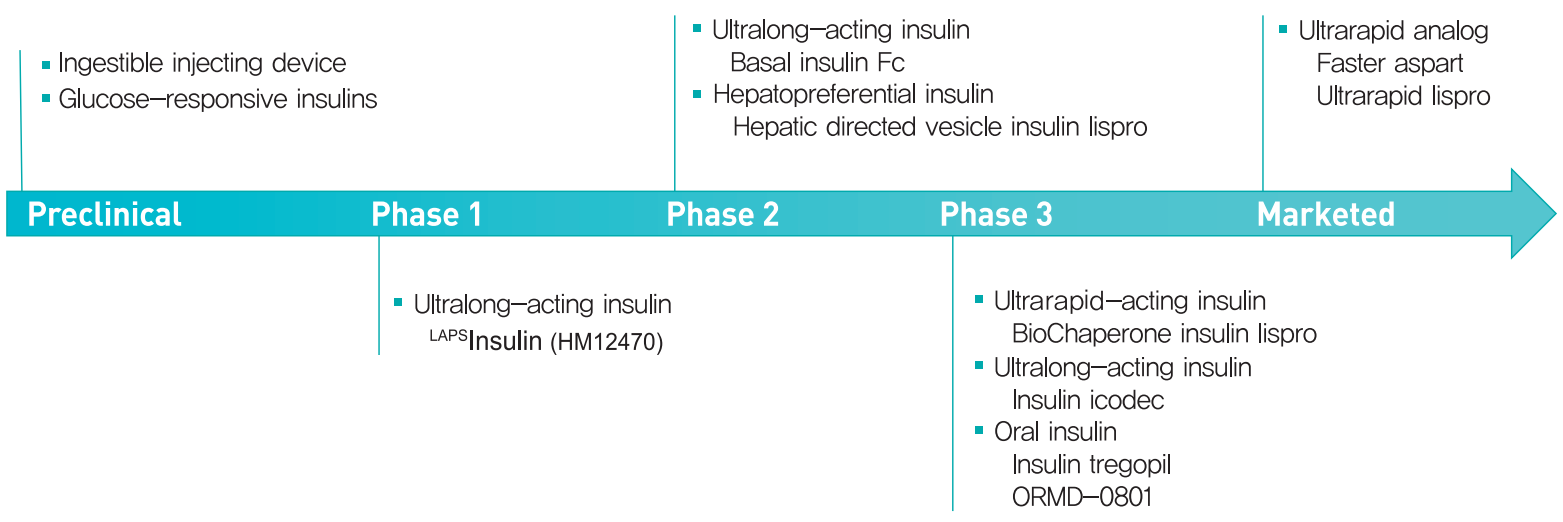

Fig. 3. The future insulins under development. 
in patients with both T1DM and T2DM $[57,58]$. In a phase 1 study in patients with T1DM, ultrarapid lispro had significantly faster insulin absorption than faster aspart, insulin aspart, and insulin lispro [56]. Another strength of ultrarapid insulin analogs is flexibility in meal scheduling. Postmeal administration of faster aspart was similarly effective as mealtime insulin aspart [54]. BioChaperone insulin lispro (Adocia, Lyon, France) is another ultrarapid-acting insulin under development. It contains a modified oligosaccharide excipient BioChaperone BC222 and citrate to promote insulin lispro hexamer dissociation and accelerate absorption. BioChaperone insulin lispro better mimicked prandial insulin secretion and significantly improved postprandial glucose compared to rapid acting insulins [59,60]. This BioChaperone technique is also being tested for various combinations, including insulin glargine plus lispro or insulin lispro plus pramlintide.

Reduced dosing frequency may improve adherence to insulin treatment and enhance convenience. It would also be easier to use for individuals who need assistance in insulin injection and would reduce treatment burden. A novel once-weekly basal insulin analog icodec is the next runner that showed favorable results in phase 2 clinical trials [61-63]. It was designed by three amino acid substitutions (A14 glutamic acid, B16 histidine, and B25 histidine) for molecular stability and reducing enzymatic degradation, removal of B30 threonine, and addition of a C20 icosane fatty diacid side chain at B29 lysine attached via a hydrophilic spacer for strong albumin binding and reduced receptor-mediated clearance [64]. Preclinical studies showed that increased albumin binding with the icodec yields a longer half-life of 196 hours. After injection, hexamers are slowly dissociated and bind to albumin to form an inactive depot. Steady state is achieved after 3 to 4 weekly doses when slow and continuous release of active icodec leads to effective, prolonged, and evenly distributed glucose lowering throughout the week. At steady state, variations in dosing time and amount cause minimal changes in the immediate glucose-lowering effect, enhancing its flexibility. In a pivotal phase 2 trial of a once-weekly insulin icodec compared with once-daily insulin glargine U100 in insulin-naïve patients with T2DM taking metformin with or without a dipeptidyl peptidase 4 inhibitor, a similar glucose-lowering effect was observed (estimated mean change in $\mathrm{HbAlc}$ from baseline: $-1.33 \%$ in the icodec group and $-1.15 \%$ in the glargine group) [63]. Some secondary and exploratory endpoints including the mean 9-point patientmeasured blood glucose level and time spent within the tight glycemic range (70 to $140 \mathrm{mg} / \mathrm{dL}$ ) measured by flash glucose monitoring were superior and insulin dose was significantly lower in the icodec group. There were no statistically significant differences in the rate of level 2 (blood glucose $<54 \mathrm{mg}$ / $\mathrm{dL}$ ) or level 3 (severe cognitive impairment) hypoglycemia between the two groups, whereas level 1 (blood glucose $<70 \mathrm{mg}$ / $\mathrm{dL})$ hypoglycemia was more frequent in the icodec group. Another phase 2 study investigated the efficacy and safety of insulin icodec when switching from once or twice daily basal insulin versus insulin glargine U100 [61]. The icodec group with a $100 \%$ loading dose at the first injection showed a significantly longer time-in-range (70 to $180 \mathrm{mg} / \mathrm{dL}$ ) and numerically larger changes in $\mathrm{HbAlc}$ from baseline compared to the glargine U100 group without increasing the risk of hypoglycemia. This study showed that adding an initial loading dose is safe and effective when switching from daily basal insulin to weekly icodec. Several phase 3 trials with different patient populations, different treatment combinations, long-term efficacy and safety, and patient-reported outcomes are ongoing. Another onceweekly insulin under development is basal insulin Fc (BIF), which is a fusion protein of the human $\operatorname{IgG} 2 \mathrm{Fc}$ domain and a novel single-chain variant of insulin. Recently introduced first in-human data showed a half-life of approximately 17 days and peakless PK profile over a 1-week dosing interval in subjects with T2DM [65]. A 32-week phase 2 study demonstrated noninferior efficacy of BIF compared with insulin degludec [66]. The data presented to date suggest the feasibility of once-weekly insulin, although more clinical trials and the issue of the difficulty of short-term adaptation need to be addressed.

\section{THE FUTURE OF INSULIN THERAPY: NONINJECTING INSULINS}

Administration of insulin via a noninjectable route would overcome various limitations and barriers of subcutaneous injection and has long been a subject of interest but with limited success [67]. The first inhalable insulin, Exubera (Pfizer Inc., New York, NY, USA), was approved and marketed in 2006 but was soon withdrawn from the market by the manufacturer due to poor sales. Intrapulmonary delivery of insulin seemed to be an attractive alternative route but failed to become popular due to cost, inconvenience of the device and procedure, high demands of instruction, and safety concerns [68]. Afrezza (MannKind, Westlake Village, CA, USA) is another ultrarapidacting inhalable insulin approved by the FDA in 2014. This is a 
dry powder of recombinant human insulin adsorbed onto an excipient of fumaryl diketopiperazine based on technosphere particle technology [69]. It has been shown to be as effective as twice daily premixed biaspart insulin when combined with insulin glargine with significantly lower weight gain and fewer hypoglycemic events [70]. A pooled data analysis including 5,505 patients in Afrezza trials showed pulmonary safety except a higher incidence of mild cough and slight reversible decline in pulmonary function relative to comparators [71].

Oral delivery of insulin is probably the most preferable method with a more physiologic portal-to-peripheral insulin ratio; therefore, various approaches are under investigation [72,73]. However, major challenges in developing oral insulins, such as interference by meal ingestion, high absorption variability, low bioavailability, and resulting commercial unviability, are still a significant obstacle to success. Phase 2 and 3 studies of prandial oral insulins, including insulin tregopil (IN-105, recombinant insulin conjugated with polyethylene glycol via an acetyl chain) [74] and ORMD-0801 (enteric coated capsule containing insulin and adjuvants to protect the protein and promote intestinal uptake) [75], failed to show impressive results to date with no or negligible glucose lowering. Basal oral insulin would be more feasible in that it could avoid food effects. Oral insulin 338 (I338) is a long-acting basal insulin ana$\log$ coformulated in a gastrointestinal permeation enhancement technology one (GIPET I) tablet with sodium caprate as an absorption enhancer and shows an extended half-life of up to 70 hours at a steady state despite relatively fast absorption. In an 8-week phase 2 trial comparing once-daily I338 with once-daily insulin glargine in insulin-naïve patients with T2DM, there were no significant differences in the efficacy measures, including fasting plasma glucose, 10-point plasma glucose concentrations, $\mathrm{HbAlc}$, fructosamine and fasting Cpeptide concentration, or safety profile, between the two groups [76]. Despite promising results, further development of I338 was discontinued because the dose required was high due to low bioavailability and therefore it was not commercially viable for mass production. Further advances in technology and biomaterials will be crucial to overcome the hurdles of developing oral insulin.

An interesting approach of delivering insulin using an ingestible device was recently published [77]. An ingestible selforienting millimeter-scale applicator inspired by a leopard tortoise's ability to passively reorient can autonomously position itself to the stomach lining, orient its injection mechanism to- ward the tissue wall, and inject a drug through the mucosa. Using a swine model, this device was shown to successfully deliver insulin and lower blood glucose levels to a similar degree as those achieved by subcutaneous injection.

\section{THE FUTURE OF INSULIN THERAPY: HEPATOPREFERENTIAL INSULINS}

Endogenous insulin secreted from the pancreas is delivered to the liver through the portal vein before entering systemic circulation and being exposed to peripheral tissues. Conventional subcutaneous insulin administration results in much greater exposure of insulin to muscle and lower exposure to liver, resulting in different degrees of action in these organs compared to physiologic endogenous insulin [78]. Hepatopreferential insulin has been suggested as an alternative to restore the physiologic portal-to-peripheral insulin ratio and reduce the risk of hypoglycemia, weight gain, and insulin resistance. Insulin peglispro is a molecule consisting of a polyethylene glycol chain covalently bound to B28 lysine of insulin lispro and has hepatopreferential effects due to its large hydrodynamic size. More than 6,000 patients with T1DM and T2DM were included in the IMAGINE phase 3 clinical trial program, and insulin peglispro consistently showed a greater $\mathrm{HbA} 1 \mathrm{c}$ reduction, less glycemic variability, reduced nocturnal hypoglycemia, and tendency to gain less weight compared to glargine and NPH [79]. Despite its potential efficacy, insulin peglispro was associated with higher liver fat and triglycerides and a higher frequency of elevation of aminotransferase levels. Although it was not due to severe liver injury, the manufacturer decided to stop the development program in 2015 [80]. Hepatic-directed vesicle (HDV) insulin is another insulin delivery system that contains biotin-phosphatidylethanolamine as a hepatocyte-targeting molecule in phospholipid bilayer vesicles [81]. In a phase $2 \mathrm{~b}$ study of T1DM, HDV insulin lispro showed noninferior HbAlc lowering and no significant differences in hypoglycemia or insulin dosing compared with insulin lispro [82]. Further delineation of its efficacy and safety is awaited.

\section{THE FUTURE OF INSULIN THERAPY: GLUCOSE-RESPONSIVE INSULINS}

Using glucose-responsive insulin (GRI), which only acts in the hyperglycemic milieu without causing hypoglycemia, would be the most ideal option for insulin treatment. However, devel- 
oping 'smart' insulin requires advances in various fields, such as formulation chemistry, protein engineering, glucose-sensing technology, and delivery devices, and many challenges still exist [83]. Because blood glucose levels fluctuate rapidly, a fastresponding system without a time lag is necessary. Additionally, to control the glucose level in a narrow normoglycemic range, insulin level or activity must be altered significantly over a narrow glucose concentration range. The glucose-reactive motif should selectively respond to glucose, and the material must be safe (nonallergenic, nontoxic) and stable for long-term use. A closed-loop insulin delivery system or artificial pancreas that uses continuous glucose monitoring and an automated pump using an intelligent algorithm is a form of mechanical GRI, and clinical application has been started $[84,85]$. There are two broad classes of molecular GRIs: (1) polymer-based systems, which consist of insulin contained within a glucoseresponsive polymeric matrix-based vesicle or hydrogel composed of glucose-binding proteins, glucose oxidase, or boronate-based chemistries, and (2) molecular-based bioconjugation systems, which introduce a glucose-sensitive motif (phenylboronic acid, glucosamine, or mannose) to the insulin molecule or its formulation. The characteristics of various GRIs have been extensively reviewed in recently published papers $[83,86]$. Although these elegant strategies remain in the early stage of development, continued progress is expected.

\section{CONCLUSIONS}

After the discovery of insulin in 1921, the last 100 years have been a history of enormous progress and remarkable advances in various fields of science linked to the development of insulins with better profiles. However, many failures have also occurred, and there seem to be many more obstacles to the cure of diabetes. We eagerly wish for continued improvement in the care of patients with diabetes, keeping Banting's positive drive and perseverance in mind.

\section{CONFLICTS OF INTEREST}

No potential conflict of interest relevant to this article was reported.

\section{ORCID}

Seung-Hwan Lee https://orcid.org/0000-0002-3964-3877
Kun-Ho Yoon https://orcid.org/0000-0002-9109-2208

\section{FUNDING}

None

\section{ACKNOWLEDGMENTS}

This work was supported by grants from the National Research Foundation of Korea (2018R1D1A1B07043223, 2021R1F1A1061197) to Seung-Hwan Lee.

\section{REFERENCES}

1. Pickup J, Williams G. Textbook of diabetes. 3rd ed. Oxford: Blackwell Science; 2003.

2. Jung CH, Son JW, Kang S, Kim WJ, Kim HS, Kim HS, et al. Diabetes fact sheets in Korea, 2020: an appraisal of current status. Diabetes Metab J 2021;45:1-10.

3. Rhee EJ. Prevalence and current management of cardiovascular risk factors in Korean adults based on fact sheets. Endocrinol Metab (Seoul) 2020;35:85-94.

4. Saeedi P, Petersohn I, Salpea P, Malanda B, Karuranga S, Unwin N, et al. Global and regional diabetes prevalence estimates for 2019 and projections for 2030 and 2045: results from the International Diabetes Federation Diabetes Atlas, 9th edition. Diabetes Res Clin Pract 2019;157:107843.

5. von Mering J, Minkowski O. Diabetes mellitus nach Pankreasextirpation. Arch Exp Pathol Pharmakol 1890;26:371-87.

6. Laguesse G. Sur la formation des ilots de Langerhans dans le pancréas. C R Soc Biol 1893;45:819-20.

7. Scott EL. On the influence of intravenous injections of an extract of the pancreas on experimental pancreatic diabetes. Am J Physiol Leg Content 1912;29:306-10.

8. Paulesco NC. Recherches sur le rôle du pancréas dans lassimilation nutritive. Arch Int Physiol 1921;17:85-109.

9. Kleiner IS, Meltzer SJ. Retention in the circulation of dextrose in normal and depancreatized animals, and the effect of an intravenous injection of an emulsion of pancreas upon this retention. Proc Natl Acad Sci U S A 1915;1:338-41.

10. Murlin JR, Kramer B. The influence of pancreatic and duodenal extracts on the glycosuria and the respiratory metabolism of depancreatized dogs. Proc Soc Exp Biol Med 1913;10:171-3.

11. Hegele RA, Maltman GM. Insulin's centenary: the birth of an idea. Lancet Diabetes Endocrinol 2020;8:971-7. 
12. Lewis GF, Brubaker PL. The discovery of insulin revisited: lessons for the modern era. J Clin Invest 2021;131:e142239.

13. Barron M. The relation of the islets of Langerhans to diabetes with special reference to cases of pancreatic lithiasis. Surg Gynecol Obstet 1920;31:437-48.

14. Banting FG, Best CH, Collip JB, Campbell WR, Fletcher AA. Pancreatic extracts in the treatment of diabetes mellitus. Can Med Assoc J 1922;12:141-6.

15. Xu X, D’Hoker J, Stange G, Bonne S, De Leu N, Xiao X, et al. Beta cells can be generated from endogenous progenitors in injured adult mouse pancreas. Cell 2008;132:197-207.

16. Van de Casteele M, Leuckx G, Baeyens L, Cai Y, Yuchi Y, Coppens $\mathrm{V}$, et al. Neurogenin $3+$ cells contribute to $\beta$-cell neogenesis and proliferation in injured adult mouse pancreas. Cell Death Dis 2013;4:e523.

17. Rankin MM, Wilbur CJ, Rak K, Shields EJ, Granger A, Kushner JA. $\beta$-Cells are not generated in pancreatic duct ligation-induced injury in adult mice. Diabetes 2013;62:1634-45.

18. Van de Casteele M, Leuckx G, Cai Y, Yuchi Y, Coppens V, De Groef S, et al. Partial duct ligation: $\beta$-cell proliferation and beyond. Diabetes 2014;63:2567-77.

19. Cavelti-Weder C, Shtessel M, Reuss JE, Jermendy A, Yamada T, Caballero F, et al. Pancreatic duct ligation after almost complete $\beta$-cell loss: exocrine regeneration but no evidence of $\beta$-cell regeneration. Endocrinology 2013;154:4493-502.

20. Brown H, Sanger F, Kitai R. The structure of pig and sheep insulins. Biochem J 1955;60:556-65.

21. Sanger F. Chemistry of insulin: determination of the structure of insulin opens the way to greater understanding of life processes. Science 1959;129:1340-4.

22. Walker J. Frederick Sanger (1918-2013). Nature 2014;505:27.

23. Howard JA. Dorothy Hodgkin and her contributions to biochemistry. Nat Rev Mol Cell Biol 2003;4:891-6.

24. Adams MJ, Blundell TL, Dodson EJ, Dodson GG, Vijayan M, Baker EN, et al. Structure of rhombohedral 2 zinc insulin crystals. Nature 1969;224:491-5.

25. Yalow RS, Berson SA. Assay of plasma insulin in human subjects by immunological methods. Nature 1959;184(Suppl 21): 1648-9.

26. Yalow RS, Berson SA. Immunoassay of endogenous plasma insulin in man. J Clin Invest 1960;39:1157-75.

27. In memoriam: Dr. Rosalyn Yalow, PhD., 1921-2011. Mol Endocrinol 2012;26:713-4.

28. Freychet P, Roth J, Neville DM Jr. Insulin receptors in the liver: specific binding of ( $125 \mathrm{I}$ )insulin to the plasma membrane and its relation to insulin bioactivity. Proc Natl Acad Sci U S A 1971;68:1833-7.

29. Cuatrecasas P. Affinity chromatography and purification of the insulin receptor of liver cell membranes. Proc Natl Acad Sci U S A 1972;69:1277-81.

30. Ullrich A, Shine J, Chirgwin J, Pictet R, Tischer E, Rutter WJ, et al. Rat insulin genes: construction of plasmids containing the coding sequences. Science 1977;196:1313-9.

31. Bell GI, Pictet RL, Rutter WJ, Cordell B, Tischer E, Goodman HM. Sequence of the human insulin gene. Nature 1980;284:2632.

32. Ullrich A, Bell JR, Chen EY, Herrera R, Petruzzelli LM, Dull TJ, et al. Human insulin receptor and its relationship to the tyrosine kinase family of oncogenes. Nature 1985;313:756-61.

33. Ebina Y, Ellis L, Jarnagin K, Edery M, Graf L, Clauser E, et al. The human insulin receptor cDNA: the structural basis for hormone-activated transmembrane signalling. Cell 1985;40: 747-58.

34. Taniguchi CM, Emanuelli B, Kahn CR. Critical nodes in signalling pathways: insights into insulin action. Nat Rev Mol Cell Biol 2006;7:85-96.

35. Saltiel AR. Insulin signaling in health and disease. J Clin Invest 2021;131:e142241.

36. Boucher J, Kleinridders A, Kahn CR. Insulin receptor signaling in normal and insulin-resistant states. Cold Spring Harb Perspect Biol 2014;6:a009191.

37. Hirsch IB, Juneja R, Beals JM, Antalis CJ, Wright EE. The evolution of insulin and how it informs therapy and treatment choices. Endocr Rev 2020;41:733-55.

38. Felig P. Landmark perspective: protamine insulin. Hagedorn's pioneering contribution to drug delivery in the management of diabetes. JAMA 1984;251:393-6.

39. Scholtz HE, Pretorius SG, Wessels DH, Becker RH. Pharmacokinetic and glucodynamic variability: assessment of insulin glargine, NPH insulin and insulin ultralente in healthy volunteers using a euglycaemic clamp technique. Diabetologia 2005; 48:1988-95.

40. Lindstrom T, Olsson PO, Arnqvist HJ. The use of human ultralente is limited by great intraindividual variability in overnight plasma insulin profiles. Scand J Clin Lab Invest 2000;60:341-7.

41. Goeddel DV, Kleid DG, Bolivar F, Heyneker HL, Yansura DG, Crea R, et al. Expression in Escherichia coli of chemically synthesized genes for human insulin. Proc Natl Acad Sci U S A 1979;76:106-10.

42. Riggs AD. Making, cloning, and the expression of human insu- 
lin genes in bacteria: the path to Humulin. Endocr Rev 2021; 42:374-80.

43. Koivisto VA. The human insulin analogue insulin lispro. Ann Med 1998;30:260-6.

44. Home PD. The pharmacokinetics and pharmacodynamics of rapid-acting insulin analogues and their clinical consequences. Diabetes Obes Metab 2012;14:780-8.

45. Bolli GB, Owens DR. Insulin glargine. Lancet 2000;356:443-5.

46. Barnett $\mathrm{AH}$. Insulin glargine in the treatment of type 1 and type 2 diabetes. Vasc Health Risk Manag 2006;2:59-67.

47. Jonassen I, Havelund S, Hoeg-Jensen T, Steensgaard DB, Wahlund PO, Ribel U. Design of the novel protraction mechanism of insulin degludec, an ultra-long-acting basal insulin. Pharm Res 2012;29:2104-14.

48. Rosenstock J, Cheng A, Ritzel R, Bosnyak Z, Devisme C, Cali AMG, et al. More similarities than differences testing insulin glargine 300 units $/ \mathrm{mL}$ versus insulin degludec 100 units $/ \mathrm{mL}$ in insulin-naive type 2 diabetes: the randomized head-to-head BRIGHT Trial. Diabetes Care 2018;41:2147-54.

49. Garber AJ, King AB, Del Prato S, Sreenan S, Balci MK, MunozTorres $\mathrm{M}$, et al. Insulin degludec, an ultra-longacting basal insulin, versus insulin glargine in basal-bolus treatment with mealtime insulin aspart in type 2 diabetes (BEGIN Basal-Bolus Type 2): a phase 3, randomised, open-label, treat-to-target non-inferiority trial. Lancet 2012;379:1498-507.

50. Bolli GB, Riddle MC, Bergenstal RM, Ziemen M, Sestakauskas $\mathrm{K}$, Goyeau H, et al. New insulin glargine $300 \mathrm{U} / \mathrm{ml}$ compared with glargine $100 \mathrm{U} / \mathrm{ml}$ in insulin-naïve people with type 2 diabetes on oral glucose-lowering drugs: a randomized controlled trial (EDITION 3). Diabetes Obes Metab 2015;17:386-94.

51. Wu T, Betty B, Downie M, Khanolkar M, Kilov G, Orr-Walker $\mathrm{B}$, et al. Practical guidance on the use of premix insulin analogs in initiating, intensifying, or switching insulin regimens in type 2 diabetes. Diabetes Ther 2015;6:273-87.

52. Ross SA. Breaking down patient and physician barriers to optimize glycemic control in type 2 diabetes. Am J Med 2013;126(9 Suppl 1):S38-48.

53. Biester T, Kordonouri O, Danne T. Pharmacological properties of faster-acting insulin aspart. Curr Diab Rep 2017;17:101.

54. Russell-Jones D, Bode BW, De Block C, Franek E, Heller SR, Mathieu $\mathrm{C}$, et al. Fast-acting insulin aspart improves glycemic control in basal-bolus treatment for type 1 diabetes: results of a 26-week multicenter, active-controlled, treat-to-target, randomized, parallel-group trial (onset 1). Diabetes Care 2017;40: 943-50.
55. Bowering K, Case C, Harvey J, Reeves M, Sampson M, Strzinek $\mathrm{R}$, et al. Faster aspart versus insulin aspart as part of a basal-bolus regimen in inadequately controlled type 2 diabetes: the onset 2 trial. Diabetes Care 2017;40:951-7.

56. Heise T, Linnebjerg H, Coutant D, LaBell E, Zijlstra E, Kapitza $\mathrm{C}$, et al. Ultra rapid lispro lowers postprandial glucose and more closely matches normal physiological glucose response compared to other rapid insulin analogues: a phase 1 randomized, crossover study. Diabetes Obes Metab 2020;22:1789-98.

57. Blevins T, Zhang Q, Frias JP, Jinnouchi H, Chang AM; PRONTO-T2D Investigators. Randomized double-blind clinical trial comparing ultra rapid lispro with lispro in a basal-bolus regimen in patients with type 2 diabetes: PRONTO-T2D. Diabetes Care 2020;43:2991-8.

58. Klaff L, Cao D, Dellva MA, Tobian J, Miura J, Dahl D, et al. Ultra rapid lispro improves postprandial glucose control compared with lispro in patients with type 1 diabetes: results from the 26-week PRONTO-T1D study. Diabetes Obes Metab 2020; 22:1799-807.

59. Heise T, Meiffren G, Alluis B, Seroussi C, Ranson A, Arrubla J, et al. BioChaperone Lispro versus faster aspart and insulin aspart in patients with type 1 diabetes using continuous subcutaneous insulin infusion: a randomized euglycemic clamp study. Diabetes Obes Metab 2019;21:1066-70.

60. Andersen G, Meiffren G, Lamers D, DeVries JH, Ranson A, Seroussi C, et al. Ultra-rapid BioChaperone Lispro improves postprandial blood glucose excursions vs insulin lispro in a 14day crossover treatment study in people with type 1 diabetes. Diabetes Obes Metab 2018;20:2627-32.

61. Bajaj HS, Bergenstal RM, Christoffersen A, Davies MJ, Gowda A, Isendahl J, et al. Switching to once-weekly insulin icodec versus once-daily insulin glargine U100 in type 2 diabetes inadequately controlled on daily basal insulin: a phase 2 randomized controlled trial. Diabetes Care 2021;44:1586-94.

62. Lingvay I, Buse JB, Franek E, Hansen MV, Koefoed MM, Mathieu C, et al. A randomized, open-label comparison of onceweekly insulin icodec titration strategies versus once-daily insulin glargine U100. Diabetes Care 2021;44:1595-603.

63. Rosenstock J, Bajaj HS, Janez A, Silver R, Begtrup K, Hansen $\mathrm{MV}$, et al. Once-weekly insulin for type 2 diabetes without previous insulin treatment. N Engl J Med 2020;383:2107-16.

64. Kjeldsen TB, Hubalek F, Hjorringgaard CU, Tagmose TM, Nishimura E, Stidsen CE, et al. Molecular engineering of insulin icodec, the first acylated insulin analog for once-weekly administration in humans. J Med Chem 2021;64:8942-50. 
65. Heise T, Chien J, Beals J, Benson C, Klein O, Moyers JS, et al. Basal insulin Fc (BIF), a novel insulin suited for once weekly dosing for the treatment of patients with diabetes mellitus. J Endocr Soc 2021;5(Suppl 1):A329.

66. Kazda CM, Chien J, Zhang Q, Chigutsa E, Landschulz W, Wullenweber P, et al. 192-OR: Glycemic control with once-weekly basal insulin $\mathrm{Fc}$ (BIF) in persons with type 2 diabetes mellitus (T2DM) using continuous glucose monitoring (CGM) in a phase 2 study. Diabetes 2021;70(Suppl 1):192-OR.

67. Owens DR, Zinman B, Bolli G. Alternative routes of insulin delivery. Diabet Med 2003;20:886-98.

68. Heinemann L. The failure of exubera: are we beating a dead horse? J Diabetes Sci Technol 2008;2:518-29.

69. Mikhail N. Place of technosphere inhaled insulin in treatment of diabetes. World J Diabetes 2016;7:599-604.

70. Rosenstock J, Lorber DL, Gnudi L, Howard CP, Bilheimer DW, Chang PC, et al. Prandial inhaled insulin plus basal insulin glargine versus twice daily biaspart insulin for type 2 diabetes: a multicentre randomised trial. Lancet 2010;375:2244-53.

71. McGill JB, Peters A, Buse JB, Steiner S, Tran T, Pompilio FM, et al. Comprehensive pulmonary safety review of inhaled Technosphere $^{\circledast}$ insulin in patients with diabetes mellitus. Clin Drug Investig 2020;40:973-83.

72. Zijlstra E, Heinemann L, Plum-Morschel L. Oral insulin reloaded: a structured approach. J Diabetes Sci Technol 2014;8:458-65.

73. Kumar V, Choudhry I, Namdev A, Mishra S, Soni S, Hurkat P, et al. Oral insulin: myth or reality. Curr Diabetes Rev 2018;14: 497-508.

74. Gregory JM, Lautz M, Moore LM, Williams PE, Reddy P, Cherrington AD. Enterically delivered insulin tregopil exhibits rapid absorption characteristics and a pharmacodynamic effect similar to human insulin in conscious dogs. Diabetes Obes Metab 2019;21:160-9.

75. Eldor R, Arbit E, Corcos A, Kidron M. Glucose-reducing effect of the ORMD-0801 oral insulin preparation in patients with uncontrolled type 1 diabetes: a pilot study. PLoS One 2013;8: e59524.

76. Halberg IB, Lyby K, Wassermann K, Heise T, Zijlstra E, Plum-
Morschel L. Efficacy and safety of oral basal insulin versus subcutaneous insulin glargine in type 2 diabetes: a randomised, double-blind, phase 2 trial. Lancet Diabetes Endocrinol 2019;7: 179-88.

77. Abramson A, Caffarel-Salvador E, Khang M, Dellal D, Silverstein D, Gao Y, et al. An ingestible self-orienting system for oral delivery of macromolecules. Science 2019;363:611-5.

78. Farmer TD, Jenkins EC, O’Brien TP, McCoy GA, Havlik AE, Nass ER, et al. Comparison of the physiological relevance of systemic vs. portal insulin delivery to evaluate whole body glucose flux during an insulin clamp. Am J Physiol Endocrinol Metab 2015;308:E206-22.

79. Jacober SJ, Prince MJ, Beals JM, Hartman ML, Qu Y, Linnebjerg $\mathrm{H}$, et al. Basal insulin peglispro: overview of a novel longacting insulin with reduced peripheral effect resulting in a hepato-preferential action. Diabetes Obes Metab 2016;18 Suppl 2:3-16.

80. Riddle MC. Lessons from peglispro: IMAGINE how to improve drug development and affordability. Diabetes Care 2016;39:499-501.

81. Geho WB, Geho HC, Lau JR, Gana TJ. Hepatic-directed vesicle insulin: a review of formulation development and preclinical evaluation. J Diabetes Sci Technol 2009;3:1451-9.

82. Klonoff D, Bode B, Cohen N, Penn M, Geho WB, Muchmore DB. Divergent hypoglycemic effects of hepatic-directed prandial insulin: a 6-month phase $2 \mathrm{~b}$ study in type 1 diabetes. Diabetes Care 2019;42:2154-7.

83. Jarosinski MA, Dhayalan B, Rege N, Chatterjee D, Weiss MA. 'Smart' insulin-delivery technologies and intrinsic glucose-responsive insulin analogues. Diabetologia 2021;64:1016-29.

84. Boughton CK, Hovorka R. New closed-loop insulin systems. Diabetologia 2021;64:1007-15.

85. Brown SA, Kovatchev BP, Raghinaru D, Lum JW, Buckingham BA, Kudva YC, et al. Six-month randomized, multicenter trial of closed-loop control in type 1 diabetes. N Engl J Med 2019; 381:1707-17.

86. Hoeg-Jensen T. Review: glucose-sensitive insulin. Mol Metab 2021;46:101107. 